\title{
Considering curriculum change: The case for Portuguese as an additional language in South African higher education
}

\author{
Anita de Melo
}

University of Cape Town, School of Languages \& Literatures

Cape Town, South Africa

anita.pereirademelo@uct.ac.za

https://orcid.org/0000-0002-8381-1575

\section{Ludmylla Mendes Lima}

UNILAB - Universidade da Integração Internacional da Lusofonia Afro-Brasileira, IHL

São Francisco do Conde, Brazil

ludmyllalima@unilab.edu.br

https://orcid.org/0000-0003-3329-4677

(Received: 23 July 2019; accepted: 14 April 2020)

\section{Abstract}

In this paper, we reflect on current discussions regarding curriculum change in South African higher education, focusing on the specific field of teaching and learning Portuguese as an additional language (PAL) in the country. Given the reality of South African multilingualism, we consider the possibility of a translanguaging pedagogy in the field of PAL. We argue that greater awareness of the full potential of multilingualism is advantageous for a more reciprocal teaching and learning process in relation to PAL. We argue that materials for upper level courses in Portuguese culture and literature in South Africa would provide postcolonial approaches and interpretations that could lead to a pedagogy of translanguaging. As an illustration, we analyse the poetry of Mozambican poet Noémia de Sousa since her ouevre reflects on colonisation, racism, slavery, black diaspora consciousness, and migration in Southern Africa from a woman's perspective. Additionally, her use of the Portuguese language provides opportunities for languages (including local) to co-exist.

Keywords: Curriculum change, Noémia de Sousa, Portuguese as an additional language, South African multilingualism, postcolonialism, translanguaging pedagogy

\section{Introduction}

In 2015, students from the University of Cape Town started the RhodesMustFall protest movement. This campaign demanded the removal of the statue of British colonialist Cecil 
John Rhodes from the campus. A month after the protest began, the statue was removed. The RhodesMustFall movement encouraged other protests which spread across the country and that evolved into demands for a thorough renovation of higher education, with a particular focus on decolonising the curriculum (Bosch, 2016). In the last years we have seen an increasing number of lecturers and authors of articles and books reflect on how to respond adequately to these calls for the decolonisation of education in South African higher education (Cordeiro-Rodrigues, 2017; Leibowitz \& Bozalek, 2015; Luckett, 2016; Mampane, Omidire \& Aluko, 2018; Voster \& Quinn, 2017; Zembylas, 2018). The University of Cape Town (UCT) launched its Curriculum Change Framework (2018), which was the result of 18 months' worth of work carried out by a group of academics, staff, and students who participated in discussions on what it would mean to decolonise higher education curricula. The UCT Curriculum Change Framework (2018) directed attention to the fact that academics "in every discipline or profession in particular have a responsibility to share with society whatever interpretation they make of these terms [colonisation and decoloniality]" (p. 19).

Consequently, in this paper we join the ongoing debate by considering curriculum change in the specific field of teaching and learning Portuguese as an additional language (PAL) in the South African higher education institutions. Information on decolonial curriculum practices in the field of teaching PAL worldwide and in South Africa is scarce, but new research about decolonising the teaching of foreign languages is taking place. ${ }^{1}$ Apart from the lack of support in the form of research, this initial discussion encounters the challenge of thinking about and working towards such curriculum change as the introduction of PAL in the unique South African multilinguistic context. We believe strongly that any discussions of, and plans to implement, curriculum change in the field of PAL in South Africa must first take into consideration the country's multilingualism.

Prior to engaging in a discussion on curriculum change in the teaching of Portuguese in South African higher education, it is important to note that we empathise with students' frustration with "the lack of engagement with African languages on campus" (The UCT Curriculum Change Framework, 2018, p. 30). We are aware that a paper on teaching yet another European (in origin) language might convey, however erroneously, a colonial attitude. Portuguese is a colonial language and in some parts of Africa many children are forced into being educated in this language instead of in their indigenous African languages. Indeed, we believe strongly that there is room for PAL educators in South Africa to address critically this fundamental injustice. As Macedo (2019) has pointed out, foreign language teachers should become "agents of history" by "engaging in critical reflection followed by knowledgeable action" (p. 34). As PAL investigators and educators, not only must we be aware of linguistic imperialism in Africa, but we must also facilitate a critical scrutiny of it. In this paper we in no way place higher importance on the teaching of colonial languages over the teaching of indigenous African languages. We believe that decolonial practices of teaching and learning PAL in the Republic of South Africa have the potential to contribute to the discussion related

A new book, Decolonizing Foreign Language Education: The Misteaching of English and Other Colonial Languages, edited by Donaldo Macedo (2019), is a promising endeavour for the calls of decolonisation in the specific field of teaching and learning foreign languages. 
to the importance of sustaining indigenous African languages. Later in this paper we suggest that critical practices of translanguaging in PAL in South Africa can be an effective tool with which to reflect on current language demands and policies.

The term translanguaging was first coined by Cen Williams in 1994, but since then it has evolved significantly as Naldic (2016) has pointed out. Translanguaging refers to practices of language teaching in multilingual spaces. It has also been used as a pedagogic approach for educators who teach foreign languages, in which the use of more than one language in the classroom is allowed. García (2017) offered a definition of translingualism that refers to "the use of the children's full linguistic repertoire to make meaning without thinking of the fact that they have one language that is different from the other." As a pedagogy, it is a "way of using all linguistic resources in order to make meaning" (00:15- 1:19). Furthermore, as questions of identity, power, and communication in multilingual individuals begin to emerge, translanguaging recognises these "multiple identities and languages" through "creating a space where values, culture, language and history can be expressed" (Kasula, 2016, p. 111).

While we recognise the struggle from translanguaging theory to practice in PAL, and that translanguaging is rather a new term in the field of linguistics, we believe that in South Africa a pedagogy of translanguaging in the field of PAL is an approach that could meet some of the demands to decolonise higher education in the country. A pedagogy of translanguaging in PAL can survey these "hybrid spaces of language" while avoiding language ideologies. (Pennycook, 2006, p. 114). Hence, we suggest that in a pedagogy of translanguaging, materials for upper level courses in PAL in South Africa would provide postcolonial approaches and allow students to access their multilinguistic backgrounds in order to make meaning and to express themselves. We suggest, too, that such expression could include any creative form of art.

In the next section we review the status of Portuguese worldwide as a first language, as a second one, and as an additional language, and focus on the African continent and in particular on South Africa. Then we review South Africa's policy regarding the promotion of local languages and teaching foreign and/or additional languages. We assess South African multilingualism and the prospect of creating translanguaging practices in the field of PAL. Finally, and as part of a suggestion for upper course materials in PAL, we present an analysis of the poetry of Noémia de Sousa with which we have been working with our South African students.

\section{The status of Portuguese worldwide}

A number of foreign languages are currently being taught in South African higher education institutions. Portuguese, as the third most spoken language after English and French on the African continent that is originally non-African with its origins in a European country, is one of them. Portuguese is the official language of five African countries, namely Angola, 
Mozambique, Guinea-Bissau, São Tomé e Príncipe, and Cape Verde. ${ }^{2}$ Since the1980s when Portuguese became the official language of several African nations, it has been promoted as an African language, with most of its African-born speakers living in Southern Africa resident in Mozambique and Angola. The community of Portuguese language countries is often referred to as Lusophone, with Portugal, Brazil, ${ }^{3}$ East Timor and the five African countries listed above making up this community. Portuguese, along with English, not only has the status of an official language in the southern Africa region, but is also a language of the African Union (UA) and the Southern African Development Community (SADC). In 1996, the socio-cultural and economic links between the Portuguese-speaking countries were made official through the creation of the Comunidade dos Países de Lingua Portuguesa (CPLP). In Africa, where Lusophone countries gained their independence from Portugal as recently as the 1970s, postcolonial discussions and Portuguese language planning contributed to the creation of a particular community, the Países Africanos de Língua Oficial Portuguesa (PALOP). ${ }^{4}$ In addition, Portuguese has a noticeable presence in the linguistic landscape of South Africa where many migrants (African, Lusophone, and Portuguese) speak it as either a mother tongue or a heritage language. The exact number of Portuguese migrants living in South Africa is disputable but is believed to be more than two hundred thousand (Lelyveld, 1981). Mozambican migrants outnumber the Portuguese in South Africa with a population of more than four hundred thousand (Factsheet, 2016). Consequently, transnational and transcultural trends coming from the Portuguese-speaking country of Mozambique are linked to migrations to the Republic of South Africa. Furthermore, the Portuguese language has gained a central role in South Africa because of the political and economic ties between the Republic and Brazil, the largest Portuguese-speaking country. Both South Africa and Brazil are members of the emerging economies known as BRICS; the acronym refers to Brazil, Russia, India, China, and South Africa. As a result of globalisation, Portuguese has become one of the major languages of the world, one of the most spoken languages in the southern hemisphere and estimated to become the major language of the Global South by 2050 (University of Coimbra, 2019). The undeniable fact that Portuguese is an international central language, and, as mentioned above, the third most spoken language in Africa, ensures its dominant position not only in the language market, but also in the cultural and literary landscapes of the world. In being interdisciplinary cores, the linguistic, the literary, and the cultural offer several perspectives to teaching and learning Portuguese.

\footnotetext{
2 The dissemination of Portuguese by the colonial power of Portugal also contributed to the formation of many creole languages. In some African nations, namely Cape Verde, Guine-Bissau, and São Tomé and Príncipe these creole languages now exist alongside Portuguese and some Indigenous African languages (Vilela 2002). It is outside the scope of this paper to discuss the status of Portuguese and Portuguese-based creole languages in Africa. However, we believe that this is an important discussion for decolonial studies in Lusophone Africa. It is relevant to point out that Brazil is the country with the largest black diaspora in the world. The vast majority of black Brazilians speak Portuguese.

It is outside the scope of this paper to discuss the status and reconfiguration of the Portuguese language in the PALOPs. Yet, and as in other African nations, the discussions regarding language planning and what constitutes a mother tongue within the PALOPs is complex. For further reading on this topic, please refer to Vilela, 2002.
} 


\section{PAL in the South African multilinguistic context: Possibilities of developing a pedagogy of translanguaging practices}

Currently, Portuguese is taught in five South African universities at the undergraduate level - the University of Cape Town, the University of Mpumalanga, the University of Pretoria, UNISA, and the University of the Witwatersrand. At the time of writing, graduate studies at the MA and $\mathrm{PhD}$ level in Portuguese are still not offered across the country; currently, the University of the Witwatersrand and the University of Cape Town offer Honours programmes in Portuguese. Undergraduate PAL courses that are offered in South African higher education institutions focus on language teaching at the lower levels of study, and at the upper levels - usually in the last year of study - the focus is on reading and writing about cultural and literary materials from the Lusophone world.

The South African Language Policy for Higher Education, first published in 1997, and amended in 2002 and again in 2017, claims to foster multilingualism in higher education in order to, as pointed out by Madiba (2010), "meet the goals of equity and transformation. With respect to equity, multilingualism is considered in this policy to be pivotal to promoting equality access and improved academic success of all students" (p. 327). The Language Policy for Higher Education does not claim to promote specifically the teaching and learning of foreign languages; its appeal is that Indigenous languages also become languages of instruction in South African universities. Although this ideal is yet to be realised, the teaching and learning of foreign additional languages enables students to gain a more profound understanding of their own cultures. The South African Language Policy for Higher Education (2017) urges "institutions to include in their policies and strategies programmes that encourage the study of foreign languages, in particular those languages that are important for the promotion of the country's culture, trade and diplomatic relations" (p. 17). The teaching and learning of a foreign language offers students and teachers several opportunities to explore multilingualism. Moreover, studies demonstrate that multilinguistic ability adds a vital component to successfully learning another language. For instance, Haukas (2015) has pointed out that "multilinguals demonstrate superior metalinguistic and metacognitive abilities, such as the ability to draw comparisons between different languages and to reflect on and employ appropriate learning strategies" (p. 1).

Hence, one of the roles of PAL educators in South Africa must be to help students realise that their multilinguistic backgrounds are beneficial in learning Portuguese or any other foreign language. In a broader sense, allowing and exploring multilingualism in the PAL classroom space can help students think critically about language structures in general and, therefore, become agents of the learning process. However, inviting the use of indigenous languages into the classroom and as part of the learning process might also result in feelings of vulnerability for educators who lack knowledge of such languages; this would include the vast majority of educators at the moment. Another barrier to the use of African languages in foreign language classrooms is that, traditionally, languages are approached as separate 
entities since it is feared that there might be so-called contamination from the home language that could interfere with the learning of the target language. However, recent research has shown that the practices of translanguaging result in successful learning across the globe as García (2009) has noted. Makalela (2015) has warned that these studies are usually carried out in bilingual classrooms, but he also reported that some studies that take national languages in South Africa into consideration show positive outcomes from the use of translanguaging among and with indigenous languages.

Still, translanguaging practices offer very limited options for PAL classrooms because at the moment, as already mentioned, PAL educators, the majority of whom in South Africa are foreigners, lack knowledge of African indigenous languages. In the near future when postgraduate studies in Portuguese are implemented in South Africa, native South Africans will likely be trained to become PAL educators and when that occurs, we envision translanguaging as a major tool in teaching Portuguese. But we also believe that even in the current context, it is possible to use some translanguaging practices in the teaching and learning of PAL in South Africa. For example, when South African students of PAL are learning a new grammar concept or new vocabulary, they may be asked to access their knowledge of both English and their home languages in order to help with the learning process. Some of our Afrikaans speaking South African PAL students, have reported that one of the first words they learn in Portuguese, biblioteca (library), is a cognate word of biblioteek in Afrikaans. They have explained that this feeling of familiarity helps to lower their anxiety levels. Another example is that Modern Portuguese has subject/verb/object sentence word order, but it allows many variations of this for stylistic and literary purposes as well as for emphasis. Modern English has the same word order but observes it more rigidly. Isi-Xhosa, however, is like Portuguese in this respect. So, Isi-Xhosa- speaking PAL students should be encouraged to access their home language in order to make meaning when they are presented with Portuguese sentence word order.

Most importantly, in order to foster a translanguaging environment, it is necessary that PAL educators position themselves as co-learners, instead of perpetuating the traditional teacherstudent hierarchy, in which knowledges and epistemologies are often passed vertically from instructors and print material to students. PAL educators must value students' backgrounds and welcome them into the learning process. For example, if a challenging Portuguese language structure is presented, PAL instructors tend to contrast English structures with the Portuguese, obviously because English is probably the only other language of which both instructor and students have knowledge. Although this is a valid strategy, there are certainly other possibilities, one of which is allowing students to think critically about this challenging structure by assessing their own native languages and any other language they might know. As already stated, multilingualism must be recognised as an essential aspect of learning a foreign language, and in order to validate multilingualism, practices of translanguaging must have a place in the teaching of PAL. Unfortunately, in the specific case of teaching PAL in South Africa, studies in this field to date are non-existent; we believe that future research about curriculum change in PAL must take into consideration translanguaging practices for 
beneficial pedagogies. The UCT Curriculum Change Framework calls attention to the relevance of practices such as translanguaging for decolonial pedagogies:

Translanguaging in whatever form inside and outside the academy must be encouraged. Learning through languages, however, must not be reduced only to decoding English concepts, but must also mean dedicated effort to develop African languages as part of knowledge production. (2018, p. 60)

A pedagogy of translanguaging does not necessarily require from PAL instructors full proficiency in local languages, but requires, rather, an awareness and consciousness of multilingualism and of linguistic and cultural interdependence. Hurst and Mona have investigated translanguaging pedagogies in South Africa and have proposed that "multilingual pedagogies are a necessary response to the current crisis in South African higher education" (2017, p. 126). They cite the elucidation that Makelela provided on translingualism that

using a large linguistic repertoire at the students' disposal is important for identity formation, that is, the choice on who one is and who one becomes. Instead of separating the self and the other, translanguaging gives room for both and legitimises their interrelationship to advancing acquisition of new knowledge (cited in Hurst \& Mona, 2017, p. 132).

Hurst and Mona also pointed out that translanguaging must be a "decolonial move" in the current South African higher education landscape (2017, p. 132). In accordance with this idea, we suggest, in the next section, that materials for PAL upper level courses be selected in order to encourage a pedagogy of translanguaging that supports the current demand for decolonisation of higher education in South Africa. As an illustration of such an approach, we analyse the poetry of Mozambican poet, Noémia de Sousa.

\section{Material for Portuguese upper level courses in South Africa: Noémia de Sousa's poetry}

As mentioned previously, PAL upper level courses in South Africa depart from teaching language structure to focus on the literatures and cultures of the Portuguese-speaking world. Critical curriculum change must demand that materials for PAL upper level courses offer opportunities to (re)think colonialism and the problems and consequences of decolonisation. Texts including films, music, and other artistic productions from Portuguese-speaking Africa usually include strong questions about the different colonialist powers on the continent. In addition, many African Portuguese-speaking authors have incorporated vocabulary from African languages into their writings and this creates an opportunity to invite translanguaging practices into the classroom. While watching a Mozambican film based on a novel in one of our classes, a Venda-speaking student recognised many words uttered by a character who speaks Shangani. The Venda language shares many similarities with Shangani, a language spoken in Mozambique that also uses many examples of Portuguese vocabulary in its dialect. 
This student reported being profoundly impacted by this use of multi languages in Mozambique, which, although similar to South Africa, is unique in the Portuguese-speaking world in Africa.

Noémia de Sousa's oeuvre denounces Portuguese colonialism in Africa from a unique position at the time during which she was living. She is the only female poet who, while living under colonial power, had her poems read and shared across Lusophone Africa, especially among fighters for independence in Angola and Mozambique. And although De Sousa composed most of her poems in the late 1940s to mid-1950s, they were compiled and published in print only in 2001 as Sangue Negro. Since this post-WWII period coincided with Mozambique's struggles for independence from Portugal, which was under the dictatorship government of Salazar, De Sousa's poems were often mimeographed and distributed among political fighters both in Mozambique and Angola (De Melo, 2012). At the time, De Sousa also joined the political struggles of her country by writing for several Mozambican papers and literary magazines, such as $O$ Brado Africano and Itinerário. In addition to her political engagement, she is referred to as the first female writer of Mozambique and is known as the mother of Mozambican poetry. "De Souza's work is imperative to the understanding of colonialism through the female perspective" (De Melo, 2012, p. 66). Essentially, her poetry denounces colonialism, racism, and slavery; in her work these injustices also coexist and are amplified by the fact that she is a woman. Also, De Sousa established transatlantic dialogues with the black diaspora consciousness. Her poem "A Billie Holiday, cantora" embodies the meaning of sisterhood.

Era de noite e no quarto aprisionado em escuridão

apenas o luar entrara, sorrateiramente,

e fora derramar-se no chão.

Solidão. Solidão. Solidão

E então,

tua voz minha irmã americana,

veio do ar, do nada, nascida da própria escuridão . . .

Estranha, profunda, quente, vazada em solidão.

E começa assim a canção: 'Into each heart some rain must fall ...'

Começava assim/ e era só melancolia/ do princípio ao fim, como se teus dias fossem sem sol/ e a tua alma aí, sem alegria ...

Tua voz irmã, no seu trágico sentimentalismo,

descendo e subindo,

chorando para logo, ainda trémula, começar rindo,

cantando no teu arrastado inglês crioulo

esses singulares 'blues', dum fatalismo

rácio que faz doer

tua voz, não sei por que estranha magia,

arrastou para longe a minha solidão . . .

No quarto às escuras, eu já não estava só! 
Com a tua voz, irmã americana, veio

todo o meu povo escravizado sem dó

por esse mundo fora, vivendo no medo, no receio

de tudo e de todos ...

O meu povo ajudando a erguer impérios

a ser excluído na vitória ...

A viver, segregado, uma vida inglória, de proscrito, de criminoso . . .

O meu povo transportando para a música, para a poesia, os seus complexos, a sua tristeza inata, a sua insatisfação ...

Billie Holiday, minha irmã americana, continua cantando sempre, no teu jeito magoado os 'blues' eternos do nosso povo desgraçado ...

Continua cantando, cantando, sempre cantando, até que a humanidade egoísta ouça em ti a nossa voz,

e se volte enfim para nós,/ mas com olhos de fraternidade e compreensão! (De Sousa, 2011, p. 134)

It was a night and in the room imprisoned in darkness no sooner had the moonlight entered, surreptitiously, and was diffused upon the floor.

Solitude. Solitude. Solitude.

And then, your voice, my American sister, came from the air, from nothing, born from the darkness itself . . .

Strange, profound, sultry, oozing with solitude ... And the song began this way: "Into each heart some rain must fall ..."

Thus it began and it was pure melancholy from beginning to end, as though your days were without sun and your soul there, without joy ...

Your voice, sister, in its tragic sentimentalism, descending and rising, crying then quickly, still trembling, beginning to laugh, singing in your drawled English Creole those singular 'blues,' of a race's fatalism and brings pain your voice, I don't know by what strange magic, chased away my solitude far from me ... In the darkened room, I was no longer alone!

With your voice, American sister, came 
my entire people enslaved without pity

throughout the world, living in fear, in distrust of everything and everyone ...

My people helping to build empires and being excluded from victory ...

To live segregated, an inglorious life, of proscription, of crime ...

My people transposing to music, to poetry their complexes, their innate sorrow, their dissatisfaction ... .

Billie Holiday, my American sister, continue singing always, in your sorrowful style the eternal "blues" of our wretched people ...

Continue singing, singing, always singing, until an egotistical humanity hears in your voice, and turns at last towards us, but with fraternal and understanding eyes! (Williams, Trans., 2006, p. 175)

Billie Holliday is the black female voice of the diaspora that comforts, however melancholically, the poet. De Sousa identifies herself with the singer to whom she refers as "my American sister," and Holiday's voice is a consolation to the poet's isolated state, in that she "chased away my solitude far from me." De Sousa feels a powerful bond of sisterhood with Holiday that is documented through communal creative fecundity; it is expressed in music and poetry, and it can affect and engage others as we see in "my people transposing to music, to poetry/ their complexes, their innate sorrow, their dissatisfaction . .." As the poem develops, the phrase "my people" becomes "our people", gradually encompassing all humankind, and hoping for the end of injustices, as expressed in the lines "continue singing, singing, always singing,/ until an egotistical humanity hears in your voice,/ and turns at last towards us,/ but with fraternal and understanding eyes!" (p. 175). Besides raising ethical questions, De Sousa's poetry triggers vivid mental images thus bestowing unique aesthetic appeal. As De Melo (2012) has pointed out, Billie Holiday's song

[m]aximized the echo of Africans' clamour that was also shouted from the New World through jazz, which challenged the pervading racism and stereotypes about blacks and tried to promote progressive and socialist politics as well as racial and social integration. The themes explored in jazz include the experience of slavery and black identity, and De Sousa's poetry identifies with such a thematic. (p. 68)

Nonetheless, in Lusophone literature her work encompasses ethics and aesthetics that are central to Mozambican identity in relation to literary tradition and culture. But her work also communicates understanding about the universal themes of oppression, liberty, and fraternity through denouncing colonialism, racism, and slavery. Furthermore, De Sousa's poetry is also relevant to the South African context. Some of her themes and characters cross the border between Mozambique and South Africa and present concerns that are relevant to thinking critically about social inequalities in Southern Africa. For example, in her poem "Magaiça", the figure of the magaíça is central to the social formation of Mozambique. Magaíça is an 
indigenous term that, in this case, refers to the Mozambican citizens who returned home from working in the gold mines of the Witwatersrand. The poem communicates that these Mozambican migrants in South Africa work in precarious circumstances in these gold mines and return home with compromised health and little payment to give to their families. The first stanza of the poem depicts the moment the magaíça arrives at the railway station in Johannesburg.

A manhã azul e ouro dos folhetos de propaganda engoliu o mamparra, entontecido todo pela algazarra incompreensível dos brancos da estação e pelo resfolegar trepidante dos comboios, tragou seus olhos redondos de pasmo, seu coração apertado na angústia do desconhecido sua trouxa de farrapos carregando a ânsia enorme, tecida dos sonhos insatisfeitos do mamparra. (De Sousa, 2001, p. 84)

The blue and golden morning of the tourist brochures overwhelmed the simpleton (mamparra), dizzy at the incomprehensible hubbub of the whites at the station and the tremulous puffing of the trains, his eyes stared with astonishment, his heart knotted by the anguish of the unknown, his bundle of rags carrying the enormous anxiety that was woven with all his wished-for dreams. (Trans. Rafael, 2012)

The first three verses gradually describe the mamparra's astonishment. For De Sousa, there is a clear difference between the two indigenous terms: magaiça and mamparra are both migrants but, while mamparra is naïve and perhaps filled with hope, magaiça is disenchanted. Mamparra, like magaiça, is also an indigenous term; it refers to the Mozambicans who migrated to South Africa in order to work in the mines of the Rand. The English translator of this poem opted to translate mamparra as "simpleton," which is one of the connotations of the term. However, De Sousa chooses mamparra in the first stanza of the poem to denote the hopes of the Mozambican worker upon arriving in South Africa. As the poem develops further, such hope fades away so De Sousa then opts to use the term magaiça, which connotes the disenchanted and abused migrant returning to his home-country. In this case the English translation obscures the linguistic richness of the poem. De Sousa incorporates these two indigenous and culturally meaningful terms into the Portuguese language with artfulness; these vocabulary borrowings from indigenous African languages 
into the Portuguese language of Mozambique are meaningful to the comprehension of particular linguistic aspects of the region. The second part of the poem reads,

\author{
E um dia, \\ o comboio voltou arfando, arfando ... \\ oh Nhanisse, voltou! \\ E com ele, magaíça, \\ de sobretudo, cachecol e meia listrada \\ é um ser deslocado, \\ embrulhado em ridículo. \\ And one day, \\ the train returned, chuffing, chuffing ... \\ oh, indeed, he has returned! \\ And on the train was the migrant \\ in an overcoat, with a scarf, striped socks, \\ an alien being \\ ridiculously attired.
}

Upon his return to his homeland, the mamparra is now referred to as magaiça (note that the translator opts to translate magaíça as migrant this time). As mentioned above, the different connotations of these two terms are vital to De Sousa's poetic purposes, in that magaiça conveys the worker's demoralised condition. This condition implies that the worker is now returning home after having gone to South Africa with high hopes but having met with perilous conditions and low pay; magaíça is, above of all, in a defeated condition. Magaíça is no longer perceived by his fellow countrymen as a local, but, rather, as an outsider. Thus, the depiction of the condition of outsider unfolds through a criticism of his appearance; he returns home wearing heavy clothes such as scarves and overcoats that are suitable for the South African cold weather but odd choices for Mozambicans. His dress includes striped socks, which are considered ridiculous. He is "an alien being ridiculously attired."

When we were introducing this poem to our South African students, most of them said that they were already familiar with the term "magaiça," but they thought it was spelled with an "s" instead of a "ç". Students also said that "magaiça" for them refers to Mozambicans in general, that they were unaware of the immigrant condition implied in this term as it is understood in Mozambique. Students came to realise that words can transit between African indigenous languages and Portuguese, and that they sometimes co-exist in a hybrid space, thus creating meaning, at least in Mozambique and in Noemia de Sousa's work. Hence, De Sousa's poem helps to raise understanding of multilingualism and translanguaging awareness, thus empowering learners, as well as building cultural appreciation and acceptance. Our students engaged in story telling about the uses of the word "magaiça" in their own communities, and this activity became a reflection of their identities and multilinguistic backgrounds. 
Fittingly, this particular poem offers an example of how a pedagogy of translanguaging aimed at interpreting PAL literary texts in globalised and multilingual South Africa can and should take effect. Furthermore, for discussions on decolonisation in the specific field of PAL, the poetry of Noémia de Sousa is meaningful and relatable to the South Africa context for its germane postcolonial themes as discussed above.

\section{Conclusion}

In this paper we proposed starting a dialogue in order to discuss curriculum change in the specific field of teaching and learning Portuguese as an additional language in South Africa. We have argued that discussions around curriculum change in PAL must understand and find ways to work collaboratively with South Africa's multilingual students. Linguistic awareness encourages not only the learning of Portuguese, but it also values the importance of indigenous languages. In South Africa's unique multilingual space, PAL educators must be trained to become aware of the possibilities of inviting translanguaging practices into the classroom so that students can think, make comparisons, and rationalise language structures using every register they know in order to create meaning. But this suggestion has yet to be researched, both theoretically and empirically, in order to validate the kinds of conclusions that can be inferred from this discussion. We are inclined to think that indigenous languages must co-exist, that they have a place in the teaching of PAL, and that English should not be the sole means through which Portuguese is taught. At this moment, we are incapable of delineating any attempts towards a methodology that fully benefits from translanguaging in South Africa PAL classrooms. As stated earlier in this paper, there is no research on this subject, and, to our knowledge, this is the first report on this topic in South Africa.

For upper level Portuguese courses, we recommend the use of content that ideally provides postcolonial interpretations as a path to a pedagogy of translanguaging, which is in line with the ideals of curriculum change. As an illustration, we analysed the poetry of Mozambican poet Noémia de Sousa since her ouevre presents an opportunity to reflect on colonisation, racism, slavery, black diaspora consciousness, and migration in Southern Africa from a woman's perspective. In addition, her use of the Portuguese language provides a hybrid space for languages (including local African languages) to co-exist. Through De Sousa's poetry, we have demonstrated that materials that come from Portuguese-speaking Africa often provide perspectives on both colonisation and decoloniality.

\section{References}

Africa Check. (2016). Factsheet: Where do South Africa's international migrants come from? (2016). Retrieved from https://africacheck.org/factsheets/geography-migration/

Bosch, T. (2016) Twitter activism and youth in South Africa: The case of \#RhodesMustFall. Information, Communication and Society, 20(2). Retrieved from https://www.tandfonline.com/doi/full/10.1080/1369118X 
Cordeiro-Rodrigues, L. (2017). The decolonial turn revisited. Education as Change, 21(3), 17. https://doi.org/10.17159/1947-9417/2017/2870

Curriculum Change Working Group University of Cape Town. (2018). Curriculum change framework feedback. Retrieved from http://www.news.uct.ac.za/news/debates/ccwg/

De Melo, A. (2012). Noémia de Sousa. In A. De Melo, Dictionary of Literary Biography: African Lusophone Writers (pp. 66-69). Detroit, MI: Gale Cengage Learning.

De Sousa, N. (2001). Sanque negro. Maputo, MZ: Associação dos Escritores Moçambicanos.

García, O. (2009). Bilingual education in the 21 st century: A global perspective. Malden, MA: Wiley-Blackwell.

García, O. (2017). What is translanguaging? https://www.youtube.com/watch?v=veylQoGrySg

Haukås, Å. (2015). Teachers' beliefs about multilingualism and a multilingual pedagogical approach. International Journal of Multilingualism, 13(1), 1-18. https://doi.org/10.1080/14790718.2015.1041960

Higher Education and Training Department South Africa (2002). Language policy for higher education. Retrieved from http://www.dhet.gov.za/Management Support/LanguagePolicyforHigherEducation.pdf

Hurst, E., \& Mona, M. (2017). "Translanguaging” as a socially just pedagogy. Education as Change, 21(2), 126-148. https://doi.org/10.17159/1947-9417/2017/2015

Kasula, A. J. (2016). Olowalu Review: Developing identity through translanguaging in a multilingual literary magazine. Colombian Applied Linguistics Journal, 18(2), 109118.

Leibowitz, B., \& Bozalek, V. (2015). Foundation provision: A social justice perspective. South African Journal of Higher Education, 29(1), 8-25. https://doi.org/:10.20853/29$1-447$

Lelyveld, J. (1981). Abundant Portuguese residents elude the South African census. The New York Times, 29 May. Retrieved from https://www.nytimes.com/1981/05/29/world/abundant-portuguese-residents-eludethe-south-african-census.html

Luckett, K. (2016). Curriculum contestation in a post-colonial context: A view from the South. Teaching in Higher Education, 21(4), 415-428. https://doi.org/10.1080/13562517.2016.1155547

Macedo, D. (2019). Decolonizing foreign language education: The misteaching of English and other colonial languages. New York, NY: Routledge. 
Madiba, M. (2010). Towards multilingual higher education in South Africa: The University of Cape Town's experience. Language Learning Journal, 38(3), 327-346. https://doi.org/10.1080/09571736.2010.511776

Makalela, L. (2015). Moving out of linguistic boxes: The effects of translanguaging strategies for multilingual classrooms. Language and Education, 29(3), 200-217. https://doi.org/10.1080/09500782.2014.994524

Mampane, R. M., Omidire, M. F., \& Aluko, F. R. (2018). Decolonising higher education in Africa: Arriving at a global solution. South African Journal of Education, 38(4), 1-9. https://doi.org/10.15700/saje.v38n4a1636

Naldic (2016). What is translanguaging? Available at https://ealjournal.org/2016/07/26/whatis-translanguaging/

Pennycook, A. (2006). Language Education as Translingual Activism. Asia Pacific Journal of Education, 26(1), 111-114. https://doi.org/10.1080/02188790600608141

Potencial Económico da Língua Portuguesa (n.d.). Retrieved from http://www.uc.pt/internationalapplicants/oportunidades/linguas/economic_potential_portuguese.pdf

Rafael L. (Ed.). (2012). Stained Glass. (L. Rafael, Trans.). Howrah, IN: Roman Books.

Vilela, M. (2002). Reflections on Language Policy in African Countries with Portuguese as an Official Language. Current Issues in Language Planning, 3(3), 306-316. https://doi.org/10.1080/14664200208668043

Voster, J., Quinn, L. (2017). The "Decolonial Turn": What does it mean for academic staff development? Education as Change, 21(1), 31-49. https://doi.org/10.17159/1947$9417 / 2017 / 853$

Williams, C. (1994). Arfarniad o ddulliau dysgu ac addysgu yng nghyd-destun addysg uwchradd ddwyieithog [An evaluation of teaching and learning methods in the context of bilingual secondary education] (Unpublished doctoral dissertation). University of Wales, Bangor.

Williams, F. (2006). Poets of Mozambique: A Bilingual Anthology. New York, NY: LusoBrazilian Books.

Zembylas, M. (2018). Decolonial possibilities in South African higher education: Reconfiguring humanising pedagogies as/with decolonising pedagogies. South African Journal of Education, 38(4), 1-11. https://doi.org/10.15700/saje.v38n4a1699 